\title{
THE EFFECT OF LEADERSHIP STYLE, MOTIVATION AND DISCIPLINE OF WORK ON THE PERFORMANCE OF EMPLOYEE OF BANK XYZ IN THE JATIWARINGIN AREA
}

\author{
Yushadi Muhammad Firza*, Hubeis Musa, Affandi Joko \\ School of business, Bogor Agricultural University, Indonesia \\ *E-mail: icanfirza@gmail.com
}

\begin{abstract}
Employee performance is one aspect that is a major concern for companies in the current era of globalization. Performance that is expected to produce the best results, so that it is also needed in the banking world needed to get new ones. There are several changing factors that influence the company between other styles, leadership style, motivation, and discipline of work. Based on the above reasons, this study aims to analyze leadership style, motivation and discipline of work towards Bank XYZ employees in the Jatiwaringin Area, with a total of 100 company respondents purposively. The method used is Structural Equation Model (SEM) using Partial Least Squares (PLS) with SmartPLS 3.0 software. The results of this study indicate that the leadership style determines the positive and significant effect on motivation and not significant to employee performance on employee discipline of work. Motivation also has a positive and significant impact on discipline of work and employee performance and positive discipline of work, but it is not significant on the performance of Bank XYZ employees in the Jatiwaringin Area.
\end{abstract}

\section{KEY WORDS}

Leadership style, motivation, discipline of work, employee performance.

Company performance is one aspect that is a major concern for companies in the current era of globalization. Performance that is expected to produce the best results, so that it is also needed in the banking world needed to get new ones. Banks with the best service support are able to get attention from the bank. Banking in the era of globalization requires banks to become banks with guaranteed good service (Muljono, 1994). Therefore, it is one of the companies that produce companies in Indonesia.

There are several changing factors that influence the company between other styles, leadership style, motivation, and discipline of work. Leadership style represents the norm of behavior that is used by someone at this time trying to influence the behavior of others or subordinates (Thoha, 2010). Leadership style that is very important for employees to manage tasks and tasks that are significantly needed to improve employee performance which impacts on the company's progress before in the banking world.

Banking companies need reliable and highly motivated human resources to work. Employees in the globalization era are required to produce the best; therefore there must be one of the company's main benchmarks in supporting company performance. Motivation is very important because motivation is the thing that causes, channel and support people to want to work hard and enthusiastically achieve optimal results.

Therefore, motivation is a process that encourages, directs, and encourages employees to be directed towards the company's goals. Discipline of work is very necessary in producing employees who have a high level of performance. Employee discipline is the nature of an employee who unconsciously meets certain organizational rules and regulations (Mangkuprawira and Hubeis, 2007). Discipline greatly influences performance within the company and is seen as a form of training for employees in implementing company rules. The $X Y Z$ Bank office to be studied is the $X Y Z$ Bank Jatiwaringin Area consisting of 26 branches and among them there are central branch offices, sub-branch offices and cash offices. XYZ Bank Jatiwaringin Area is ranked second at the national level in the employee performance category in 2017.

The following is presented secondary data of Key Performance Indicator (KPI) with the 
type of full branch office and supporting branch taken from Bank XYZ Jatiwaringin Area in December 2016 until December 2017.

Table 1 - KPI of Bank XYZ Area Jatiwaringin in December 2017

\begin{tabular}{ccccc}
\hline No & Branch Name & Type & KPI Dec 2016 & KPI Dec 2017 \\
\hline 1 & Bekasi Jatiwaringin & B1 & 103.23 & 114.07 \\
2 & Bekasi Sentra Niaga Kalimalang & B2 & 95.77 & 100.20 \\
3 & Bekasi Ahmad Yani & B1 & 103.88 & 112.33 \\
4 & Bekasi Kemang Pratama & B2 & 106.77 & 104.14 \\
5 & Bekasi Pondok Gede Raya & B2 & 103.51 & 94.00 \\
6 & Bekasi Taman Galaxy & B2 & 94.14 & 109.60 \\
7 & Bekasi Jaka Sampurna & B3 & 101.92 & 103.30 \\
8 & Bekasi Komsen Jati Asih & B2 & 80.26 & 103.94 \\
9 & Cibubur Citra Grand & B3 & 95.13 & 105.53 \\
10 & Bekasi Ujung Aspal & B3 & 88.28 & 112.56 \\
\hline
\end{tabular}

Viewed from Table 1, there was a decrease in KPI for several branch offices from 2016 to 2017, namely the Bekasi Branch Office (KCP) Kemang Pratama with a decrease of 2.63 points from 106.77 to 104.14 and Bekasi KCP Pondok Gede Raya 9.51 points from 103.51 to 94.00. In addition to these two offices, there was an increase in other branch offices. The eight other branch offices increased and only left two branch offices. The decrease in KPI can be influenced by leadership style and employee motivation. This affects employee discipline of work because delay indicates a lack of discipline of work from employees. Table 1 also proves that leadership style and motivation and discipline of work are influencing factors in improving performance (Pawirosumarto et al. 2017). Based on the results of interviews with the Head of the Jatiwaringin Area Branch, Bank XYZ wanted to know the effects of 3 variables, namely, leadership style, motivation and discipline of work on employee performance at Bank XYZ Jatiwaringin Area. Thus, leadership style, motivation, and good discipline of work can be expected to affect the results of employee performance for the company.

Based on the description, the formulation of the problem in this study are: 1 . What are the leadership styles, motivations, and work discipline of $X Y Z$ bank employees in the Jatiwaringin Area?, 2. How does the leadership style and motivation influence the work discipline of the $X Y Z$ bank employees in the Jatiwaringin Area?, 3. How does the influence of leadership style, motivation and work discipline on the performance of the $X Y Z$ bank Jatiwaringin Area.

This study aims to know and analyze the leadership style, motivation, and discipline of work of Bank XYZ employees in the Jatiwaringin Area, to know and analyze the influence of leadership style and motivation on the discipline of Bank XYZ Jatiwaringin Area employees and to know and analyze the influence of leadership style, motivation and discipline of work on the performance of Bank XYZ employees in the Jatiwaringin Area.

\section{LITERATURE REVIEW}

One of the most important aspects in improving performance is leadership style. The leadership style in the banking sector is needed by leaders, because it can provide direction to its employees. Leadership style is a way used by leaders in interacting with their subordinates (Tjiptono, 2006). Another theory about leadership style is the path- goal theory of leadership. Path-goal theory leadership is a leadership theory which states that there are two contingency variables that link leadership behavior with results in the form of job satisfaction and performance. Basically, path-goal theory seeks to explain the influence of leader behavior on motivation, satisfaction, and execution of the work of subordinates. In table 2, House (1996) suggests a path-goal theory of four main types or styles of leadership.

Herzberg (1987) revealed in the theory of two motivational factors in carrying out their work, employees were influenced by two main factors, namely Maintenance / Hygienic Factors (Factors of Maintenance or Hygiene) and Motivation Factors listed in Table 3. 
Table 2 - Types or styles of leadership

\begin{tabular}{ll}
\hline Type of Leadership Style & Definition \\
1 Directive Leadership Style & $\begin{array}{l}\text { This leadership style has the perception that: the leader as a whole directs his } \\
\text { subordinates and subordinates know exactly what is expected of him to the } \\
\text { leader. }\end{array}$ \\
\hline 2 Supportive Leadership Style & $\begin{array}{l}\text { This leadership style has the perception that: Leaders have a willingness to } \\
\text { explain themselves, be friendly, approachable, and have genuine human } \\
\text { concern for their subordinates. }\end{array}$ \\
\hline 3 Participatory Leadership Style & $\begin{array}{l}\text { This leadership style has the perception that: The leader tries to ask and use } \\
\text { the suggestions from his subordinates. But decision making is still at the } \\
\text { leader hands. }\end{array}$ \\
\hline $\begin{array}{l}\text { This leadership style has the perception that: The leader sets a set of goals } \\
\text { Leadership Style }\end{array}$ & $\begin{array}{l}\text { Thing } \\
\text { that challenge his subordinates to participate. The leader also gives } \\
\text { confidence to his subordinates capable of carrying out work tasks properly. }\end{array}$
\end{tabular}

Hygiene factors are factors that are important for motivation in the workplace. This factor does not lead to positive satisfaction for the long term. But if these factors are not present, then dissatisfaction arises. This factor is extrinsic factors to work. Hygienic factors are called dissatisfiers or maintenance factors needed to avoid dissatisfaction. Hygiene factors are pictures of individual physiological needs that are expected to be fulfilled. Hygiene factors include salary, personal life, quality of supervision, working conditions, job security, interpersonal relationships, wisdom, and company administration.

Motivation Factor According to Herzberg, hygiene factors cannot be considered as motivators. Motivational factors must produce positive satisfaction. The factors inherent in the work and motivating employees for a superior performance are called satisfaction factors. Employees only find valuable intrinsic factors in motivation factors. The motivators symbolize psychological needs that are perceived as additional benefits. Motivation factors associated with the content of work include success, recognition, the work itself, improvement and growth in work.

According to Mangkuprawira and Hubeis (2007) employee discipline is the nature of an employee who consciously adheres to certain organizational rules and regulations. Discipline of work is a tool or method used by a company to influence the behavior of its employees in order to obey the rules and regulations in the company in achieving the objectives of the company (Rivai, 2009). Based on that definition, the factors as well as indicators those influence employee disciplines of work by (Soedjono, 2000) are:

- Punctuality: It can be interpreted that the accuracy that means in accordance with the rules that apply, while time is the whole series when the process, action, or circumstances are in or take place;

- Obedience to regulations: The rules of the company, both written and unwritten, are made so that within the organization's goals can be achieved properly, it requires employees who are obedient to the rules and loyal to the company, as well as the goals of the organization;

- High responsibility: The responsibility given by the company to employees is carried out as well as possible, completing it according to the burden given and according to the procedure, and being responsible if something goes wrong with the results of the work that has been done;

- Maintenance of Office Equipment: Office equipment is one of the important components in carrying out activities, so that activities can go according to plan and smoothly.

Performance is what employees do, so there is something that influences the combination of organizational employees, namely output quantity, output quality, output period, workplace presence and cooperative attitude (Mathis and Jackson, 2002). Performance that is assessed in a company is one of the employee's performance, namely how the employee does the work that has been charged to him. Performance indicators according to Mangkunegara (2005) include several parts, namely:

Work Quantity. This amount of work is adjusted to the existing working time, which 
needs to be considered not the routine results but how quickly the work can be completed in a time and the more work completed, the better the performance of its employees.

Work Quality. The quality of work is achieved based on the requirements of suitability and work readiness of employees. The quality of work provided is those that meet the SOP (Standard Operational Procedures) requirements.

Timeliness of Work. Associated with carrying out activities in a timely manner. Timeliness shows the effectiveness of using the available time allocation. This is very important in the banking world where it covers money issues.

\section{CONCEPTUAL FRAMEWORK}

Theoretical research framework which is shown in the description above can be explained through a systematic overview of a study as seen from Figure 1. Some of the previous research related to leadership style, motivation and discipline of work and their implications on the employee performance are mentioned in this following section:

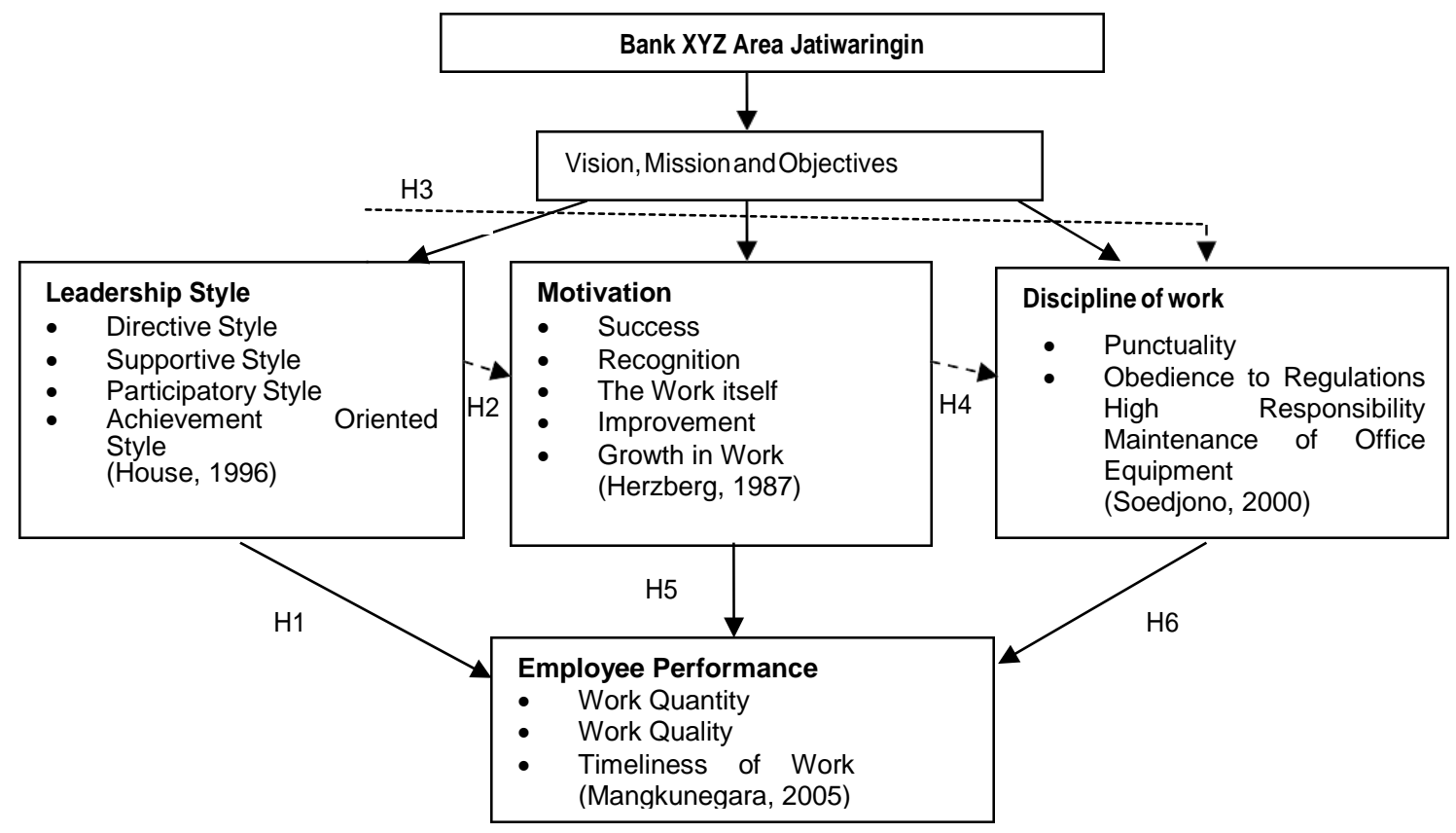

Figure 1 - Conceptual framework

\section{METHODS OF RESEARCH}

The study was conducted at PT Bank XYZ Jatiwaringin Area which is a state-owned company. PT Bank XYZ Jatiwaringin Area covers the Bekasi area and its surroundings. This research was conducted from September to November 2018, to collect primary data and secondary data. Primary data obtained from questionnaires distributed to respondents and interviews with informants of Human Capital Division (HC) Bank XYZ Jatiwaringin Area, while secondary data was obtained from the relevant institutions. The number of samples taken in this study was 100 samples selected purposively, with the criteria of 1 branch head and 9 employees at each branch office (B1-B3 Type).

Processing and analysis of data in this study was carried out by instrument testing, descriptive analysis, and PLS to analyze SEM models. The instrument test was conducted to determine the validity and reliability of the questionnaire; this was done by testing the items in the questionnaire given to the respondents. If declared valid, then the question is used for the next discussion. Research begins by analyzing leadership style, motivation, discipline of work, and employee performance. Based on this, the hypothesis is formulated, namely: $(\mathrm{H} 1)$ Leadership style has a significant effect on employee performance, (H2) Leadership style 
has a significant effect on employee motivation, $(\mathrm{H} 3)$ Leadership style has a significant effect on employee discipline of work. (H4): Motivation has a significant effect on employee discipline of work, (H5) Motivation has a significant effect on employee performance and $(\mathrm{H} 6)$ Discipline of work has a positive and significant effect on employee performance. In this study, the data analysis used is Structural Equation Modeling (SEM) with the partial least square (PLS) approach using SmartPLS 3.0 software. PLS is a component or variant based model. PLS is a multivariate statistical technique that can handle many response variables and explanatory variables at once (Geladi and Kowalski, 1986).

\section{RESULTS AND DISCUSSION}

The results of data collection from questionnaires to Bank XYZ employees at the Jatiwaringin area branch types B1 - B3 show several characteristic groups based on demographic data as shown in Table 3.

Table 3 - Distribution of respondents based on demographic aspects

\begin{tabular}{cccc} 
Information & Respondent Group & Number of People & Percentage (\%) \\
\hline \multirow{2}{*}{ Gender } & Men Women & 25 & 25 \\
& $20-30$ & 75 & 75 \\
\hline \multirow{2}{*}{ Age } & $31-40$ & 42 & 42 \\
& $41-50$ & 34 & 34 \\
& $>50$ & 13 & 13 \\
\hline \multirow{2}{*}{ Length of Work } & $>5$ th & 11 & 11 \\
\hline \multirow{2}{*}{ Last Education } & $5-15$ th & 30 & 30 \\
& $>25$ th & 48 & 48 \\
& SMA/SMK & 11 & 11 \\
\hline
\end{tabular}

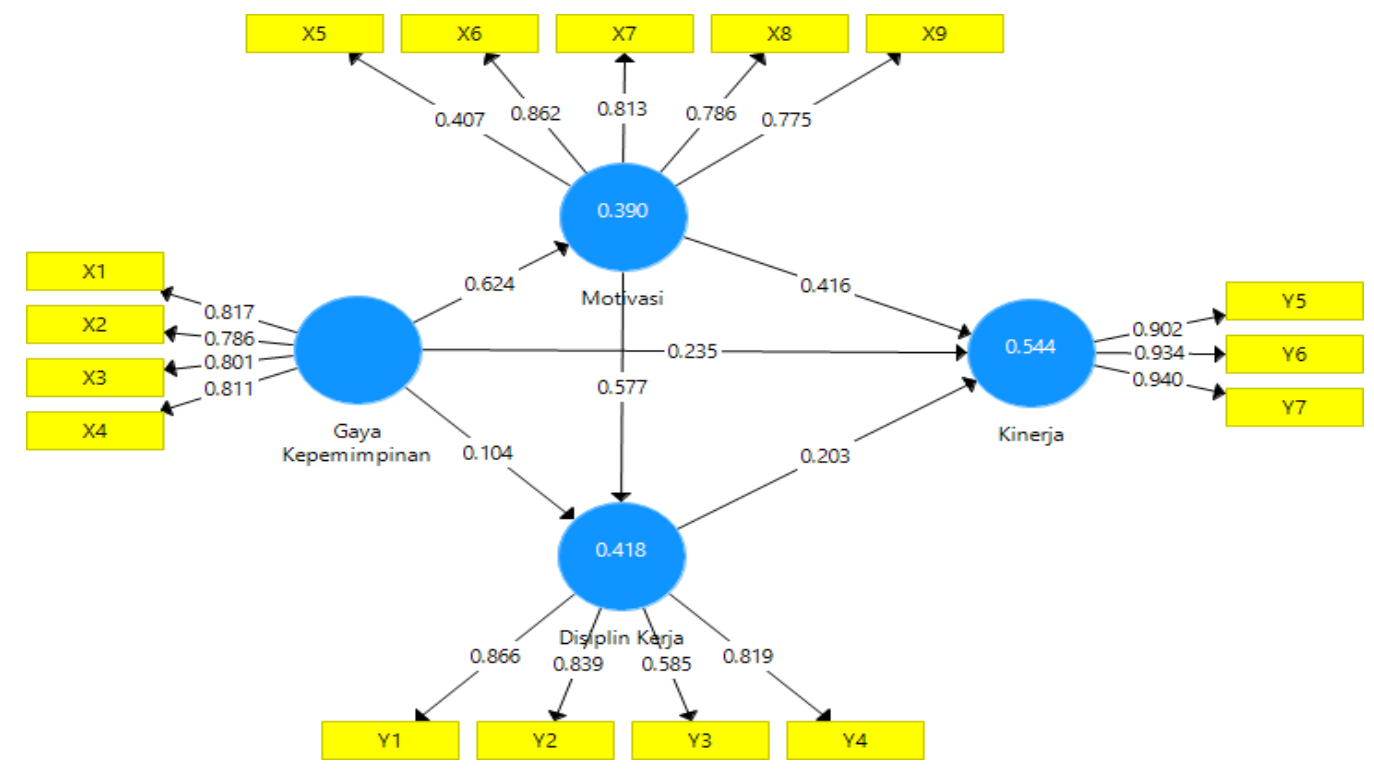

Figure 2 - Results of data processing model from SmartPLS

Observations recorded through questionnaires show that the majority of employees are women with a percentage of $75 \%$, gender affects employee productivity (Mangkunegara 2005). For this reason, adjustments in recruitment are very important to adjust the company's needs for labor. The distribution of the age of the largest respondents is $20-30$ years old with a percentage of $42 \%$. This age belongs to the $Y$ generation born between 1979 and 1996 (20-30 years). Generation $Y$ has criteria such as being on time, making a difference, having 
tolerance, managing the environment well, original, family oriented, having a broad perspective, sticking to technology, loving personal freedom and having good teamwork (Hammil 2005). Bank XYZ Jatiwaringin Area has employees in the productive age category, namely at the age of 20-40 years, making it easier for these individuals to improve their performance, because it is very needed by the company to develop and maximize the potential of its employees. Then based on his tenure, $48 \%$ of employees have a service life of more than 5 years. This shows that a number of employees at Bank XYZ Jatiwaringin Area have good loyalty to the company. In the education level, $76 \%$ of employees have a S1 background which indicates that Bank XYZ employees in the Jatiwaringin Area have employees who have a fairly high education standard.

Evaluation of the reflection indicator model: (1). reliability of individual items, (2) internal son or construct reliability, and (3). the average variance is extracted (1-3 stages of convergent validity) and (4). discriminant validity. The measurements in this study are categorized into convergent validity. From checking the reliability of individual items, it can be seen from the value of loading factors. Contains assessment factors with indicators between constructs. The loading factor value is used for validity instructions. The measurement results of Leadership Style in Figure 2 show that the directive style indicator has the highest value of 0.817 . This shows that the directive style plays an important and influential role in determining the leadership style of the Bank. Giving directives from superiors can increase motivation and discipline of work that affect employee performance. The measurement results of Motivation in Figure 2 show that the Recognition indicator has the highest value of 0.862 . This shows that the recognition received by employees can affect discipline of work and employee performance at Bank XYZ Jatiwaringin Area. Giving awards regularly can give recognition to these employees. The results of the measurement of discipline of work variables in Figure 2 show that the indicator of timeliness has the highest value of 0.866 . This shows that the timeliness in work is very influential for employee discipline and can have an impact on employee performance. Time to enter work and rest time plays an important role in increasing employee discipline. The measurement results of employee performance variables in Figure 2 show that the indicator of work timeliness has the highest value of 0.940. This shows that the timeliness in completing work greatly affects employee performance. Appropriate work time and providing services in a timely manner to customers and prospective customers can affect employee performance.

Table 4 - AVE and Composite Reliability

\begin{tabular}{ccc}
\hline Latent Variable & AVE & Composite Reliability \\
\hline Leadership Style & 0,617 & 0,863 \\
Motivation & 0,558 & 0,857 \\
Discipline of work & 0,646 & 0,879 \\
\hline Employee Performance & 0,857 & 0,947 \\
\hline
\end{tabular}

The model has good validity if each latent variable with a reflective indicator has AVE> 0.5 , while it will be reliable if the latent variable has a composite reliability value of more than 0.7 . The analysis shows that the AVE value of each latent variable has a value $>0.5$ and all latent constructs have a composite reliability value of more than 0.7 so that it can be said that the PLS model meets good convergent validity requirements and has good, accurate and consistent reliability.

Testing the inner model or structural model is done by looking at the R-square of the research model. Data from the R-square estimation can be seen in Table 5.

Table 5 - Value of R-square and R-square adjusted

\begin{tabular}{ccc}
\hline Variable & R-square & R-square Adjusted \\
\hline Disiplin Kerja & 0.418 & 0.406 \\
Kinerja & 0.544 & 0.530 \\
Motivasi & 0.390 & 0.384 \\
\hline
\end{tabular}


From the R-square value above, that means:

- Leadership and Motivation Style can explain the diversity of Discipline of work $40.6 \%$ and the rest $(59.4 \%)$ can be explained by other variables outside of the research;

- Leadership Style, Motivation, and Discipline of work are able to explain the diversity of Performance $53 \%$ and the rest $(47 \%)$ can be explained by other variables outside of the research;

- The Leadership Style can explain the diversity of Motivation by $38,4 \%$ and the rest $(61,6 \%)$ can be explained by other variables outside of the research. The value of $R 2$ is $0 \leq R 2 \leq 1$, if $R 2$ is partially closer to 1 , the better the suitability of the model with data (Gujarati 1995). This $R$-square value is good enough.

Hypothesis testing. According to Zikmund (1997) hypotheses are propositions or conjectures that have not been proven that tentatively explain facts or phenomena, as well as possible answers to research questions. In PLS, testing each relationship is done by simulating the bootstrapping method for the example. The bootstrapping method is a sample data- based resampling method with a return requirement on the data to complete the size statistics of an example in the hope that the sample represents actual population data.

$\mathrm{HO}$ : The i-variable has no significant effect on the response $\mathrm{H} 1$ : The i-variable has a significant effect on the response And reject $\mathrm{H} 0$ when $\mathrm{p}$-value $<0,05$ or thit $>1,96$.

Table 6 - Path coefficient values between latent variables

\begin{tabular}{cccccc}
\hline $\mathrm{n} / \mathrm{n}$ & Original Sample $(\mathrm{O})$ & Sample Mean $(\mathrm{M})$ & Standard Deviation (STDEV) & T-Statistic & P-Values \\
\hline DK - KN & 0.203 & 0.201 & 0.107 & 1.888 & 0.060 \\
GK - DK & 0.104 & 0.106 & 0.093 & 1.116 & 0.265 \\
GK - KN & 0.235 & 0.230 & 0.084 & 2.809 & 0.005 \\
GK - MT & 0.624 & 0.632 & 0.064 & 9.722 & 0.000 \\
MT - DK & 0.577 & 0.583 & 0.088 & 6.581 & 0.000 \\
MT - KN & 0.416 & 0.423 & 0.106 & 3.914 & 0.000 \\
\hline
\end{tabular}

Note: *) significant influence on alpha level $5 \%$.

Based on the above table, we can conclude:

- Leadership style has a significant and positive effect on employee performance with a coefficient of 0.235 . This result is evident at $5 \%$ alpha level because the $p$-value $(0.005)$ is smaller than (0.05). This shows the better leadership style, then the performance of these employees will increase and vice versa;

- The leadership style towards employee motivation also has a positive and significant influence which is equal to 0.624 . This result is evident at $5 \%$ alpha level because the $p$-value $(0.000)$ is smaller than (0.05). This shows that the higher the leadership style, the motivation of employees will increase and vice versa;

- The leadership style of discipline of work has a positive influence, but it is not significant with a coefficient of 0.104 . This result is not significant at $5 \%$ alpha level because the $p$-value $(0.265)$ is greater than $(0.05)$. This shows that the better the leadership style, the employee discipline of work will increase even though it is not large;

- Motivation towards discipline of work has a significant and positive influence with a coefficient of 0.577 . This result is evident at $5 \%$ alpha level because the $p$-value $(0.000)$ is smaller than (0.05). This shows the better employee motivation, employee discipline of work will increase and vice versa;

- Motivation on employee performance has a significant and positive influence and with a coefficient of 0.416 . This result is evident at $5 \%$ alpha level because the $p$-value $(0.000)$ is smaller than (0.05). This shows that the better employee motivation, the better the employee's performance and vice versa;

- Discipline of work on employee performance has a positive effect but not significant with a coefficient of 0.203 . This result is not significant at the $5 \%$ alpha level because the $p$-value $(0.060)$ is greater than $(0.05)$. This shows that the better the discipline of work of employees, the employee's performance will increase but not significant. 
Managerial Implications. Based on the results of the study, several things that need to be considered by Bank XYZ Jatiwaringin Area are:

- Leadership style is an influential variable in increasing employee motivation and performance. In this case, a leadership style that is suitable for subordinates will motivate employees and will improve their performance because they get the right direction from the boss, so the work can be done accordingly and the results are satisfactory;

- The motivation variable is a variable that has a positive and tangible effect on improving work discipline and employee performance. Awarding as a form of recognition among coworkers has a real influence on work discipline and employee performance in the office, because employees will be more disciplined in their work if the employee is motivated to produce the best performance;

- The variable discipline of work is a variable that influences employees' performance. The accuracy of work attendance, responsibility, maintenance of office equipment and compliance with regulations did not significantly influence the performance of Bank XYZ employees at the Jatiwaringin branch.

\section{CONCLUSION AND RECOMMENDATIONS}

In producing good employee performance, there must be a close relationship between leadership style, motivation and discipline of work. The results of the study showed that leadership style had a positive and significant effect on employee motivation and performance but was not significant for employee discipline of work. Motivation also has a positive and significant effect on discipline of work and employee performance and discipline of work have a positive effect, but not significant on employee performance.

Based on the results of the study, the advice that can be used as material for further research is to choose a sample of research based on more objective suggestions and discuss other different factors such as work environment, job satisfaction, organizational citizenship behavior and others. Increase the choice of alternative research in a wider distribution space such as region or center. Giving direction that is right on target and understanding what leadership style matches employees will increase motivation, work discipline and employee performance.

\section{REFERENCES}

1. Geladi P, Kowalski BR. 1986. Partial least-squares regression: a tutorial. Analytica Chimica Acta. 185. 1-17.

2. Ghozali I. 2008. Structural Equation Modelling, $2^{\text {nd }}$ Edition. Semarang[ID]: BP-Undip.

3. Hammil G. 2005. Mixing and Managing four generations. FDU Magazine winter/spring.

4. Hasibuan, Malayu S.P. 2006. Manajemen Dasar, Pengertian, and Masalah, Edisi Revisi. Jakarta [ID]: Bumi Aksara.

5. Herzberg FI. 1987. One More Time: How Do You Motivate Employees? Harvard Business Review. 65(5) 109-120.

6. House RJ. 1996. Path goal Theory of Leadership: Lessons, Legacy, And a Reformulated Theory. Leadership Quarterly. 7(3). 323-352.

7. Mangkuprawira TS, 2007. Manajemen Mutu Sumber Daya Manusia. Bogor [ID].

8. Muljono TP. 1994. Bank Auditing: Petunjuk Pemeriksaan Intern Bank, $4^{\text {th }}$ Ed. Jakarta.

9. Pawirosumarto S., 2017. The effect of work environment, leadership style, and organizational culture towards job satisfaction and its implication towards employee performance in Parador Hotels and Resorts. Int. J. of Law and Man. 59(6):1337-1358.

10. Soedjono. 2000. Straregi Sumber Daya Manusia untuk Pengendalian Jumlah Pendapatan Asli Daerah. Ekuitasn 4(4), 233-256.

11. Stoner JAF, 1996. Manajemen, Jilid I. Jakarta [ID]: Prenhalindo.

12. Thoha M. 2010. Perilaku Organisasi Konsep Dasar and Aplikasinya, Jakarta [ID].

13. Zikmund WG. 1997. Business Research Methods. New York [US]: Dryden Press. 